\title{
Língua portuguesa na Guiné-Bissau e a influência do crioulo na identidade cultural e no português
}

\author{
Ciro Lopes da Silva \\ Pascoal Jorge Sampa
}

Universidade da Integração Internacional da Lusofonia Afro-Brasileira (UNILAB)

\section{Considerações iniciais}

A Guiné-Bissau é um país com o território de $36.125 \mathrm{~km}^{2}$ e com a população estimada em 1.520.830 habitantes (INE, 2009). O país fica situado na costa ocidental da África, fazendo fronteira ao norte com a República do Senegal, ao sul e leste com a República de Guiné Conacri, é banhado a oeste pelo oceano Atlântico. Proclamou a sua independência unilateralmente em 24 de Setembro de 1973, sendo o primeiro país das colônias portuguesa na África a tornar-se livre do jugo colonial.

O país tem mais de 20 grupos étnicos, que se encontram por toda parte de seu território, organizados, conscientemente ou não, por regiões administrativas, onde se pode encontrar uma maior concentração de um grupo étnico em comparação ao outro. E cada um desses grupos étnicos tem a sua própria língua, o que torna a Guiné-Bissau um país pluricultural, com grande diversidade étnica e linguística. Alguns grupos apresentam pequenas semelhanças linguísticas, no que se refere à forma de chamar algumas coisas, objetos, animais, etc., principalmente em nível fonológico, como o exemplo das etnias mancanha, manjaca e papel.

Quadro 1: Etnias que apresentam semelhanças na Guiné-Bissau

\begin{tabular}{|c|c|c|c|c|}
\hline Língua & Português & Mancanha & Manjaca & Papel \\
\hline \multirow{3}{*}{ Vocábulos } & Pessoas & Banham & Banhan & Banhars \\
\cline { 2 - 5 } & Vaca & Uit & Uit & Oit \\
\cline { 2 - 5 } & Homem & Nhintch & Nintch & Nhisr \\
\hline
\end{tabular}

Fonte: Elaboração Própria

As etnias expostas no quadro apresentam grande aproximação linguística entre si, no que diz respeito à fonologia, como também em alguns traços culturais, 
em comparação com outros grupos étnicos que existem e fazem parte do mosaico cultural da Guiné-Bissau:

\begin{abstract}
É preciso ressaltar que muitas variedades linguísticas tidas como "línguas" diferentes não passam de "nomes" diferentes para dialetos de uma mesma língua. Por exemplo, Mane (2001) defende a tese de que manjaco, mancanha e papel podem ser considerados como três dialetos de uma mesma língua, com base no fato de que a fonologia dos três é idêntica, exceto algumas variantes alofônicas, o que para a sociolinguística variacionista, e para a fonologia, não seria nenhum problema. Porém, os linguistas já admitem que a distinção entre língua e dialeto é meramente política (Couto; Embaló, 2010, p. 31).
\end{abstract}

Por sua vez, há etnias que não apresentam semelhanças tão próximas, nesse caso podemos confrontar as três citadas no quadro 1 com as etnias bijagós, balantas, fulas etc. Esses grupos étnicos não têm tantas semelhanças em nível fonológico, ainda assim, podemos encontrar pequenas semelhanças entre eles em outros aspectos de ordem sociocultural, como nos rituais de iniciação (da fase de adolescente para a vida adulta) ou nos rituais fúnebres.

Além das línguas étnicas, há também no cenário linguístico da Guiné-Bissau a língua crioula, que, segundo o INE (2009, p. 36), é falada por mais de 90,4\% da população guineense, de todos os grupos étnicos em diferentes faixas etárias, mesmo não sendo ainda considerada pelas autoridades do país como uma língua oficial da Guiné-Bissau. "O crioulo é o principal meio de comunicação no seio da população. Com efeito, esta língua é utilizada por $90,4 \%$ da população em estudo [...]. A população que sabe falar a língua portuguesa corresponde a 27,1\%, e, apenas 5\% sabe falar o francês" (INE, 2009, p. 36). Basta ver as estatísticas para descobrir que o crioulo é usado para quebrar as barreiras existentes, no que diz respeito às várias línguas étnicas que existem no país, como também nas trocas comerciais, nos meios de comunicação social (rádio), nos três poderes do estado (executivo, legislativo e judiciário) e, principalmente, nos debates e discussões que decorrem na Assembleia Nacional Popular e em diversos lugares no país. Existem notícias que são veiculadas nas rádios em português, mas grande parte da grelha de programação passa em crioulo.

Em função desses elementos, é possível evidenciar a língua crioula como uma língua franca, por ser falada por quase toda a população guineense, pois mesmo as pessoas que não a usam no dia a dia, de alguma forma, sabem-na falar. Por meio dela, os diferentes grupos étnicos conseguem se comunicar e se relacionar em harmonia, pois é o elo de comunicação entre diferentes etnias. Segundo Couto e Embaló (2010, p. 28) 
mesma língua, [...] Estas línguas coabitam com o crioulo, língua veicular e de unidade nacional, e com o português, língua oficial, ambas resultantes da colonização portuguesa.

Partindo desse ponto de vista, o trabalho ora apresentado debaterá os seguintes questionamentos: até que ponto a Guiné-Bissau pode e deve ser considerado um país cuja língua oficial é o português (sendo uma língua minoritária em relação ao crioulo e à língua fula)? Será que o crioulo é um mero disfarce dos guineenses por não terem dominado o português? Ou o crioulo merece mais que o valor a ele atribuído? Como ele impacta a cultura do país e a própria língua portuguesa? Ou seja, de que modo o crioulo influencia no aprendizado do português (ajuda/ atrapalha) e na vida cotidiana dos guineenses? Por que é tido como o símbolo da unidade nacional e da identidade cultural?

Essas são as nossas motivações iniciais para desenvolver este capítulo. Além disso, pautamo-nos nos seguintes objetivos: a) Trazer ao debate as variações da língua portuguesa falada na Guiné-Bissau, comparando com os restantes países que têm essa língua como oficial e, em particular, os países africanos da expressão portuguesa. b) Considerar a importância do crioulo no dia a dia dos guineenses, não só pelo número de falantes que tem, mas também o seu impacto na identidade cultural do país e as suas influências no português falado na Guiné-Bissau.

Como objetivos específicos pretende-se explicar os conflitos existentes entre o português e o crioulo na Guiné-Bissau; discutir sobre as peculiaridades do português falado na Guiné-Bissau; e mostrar a evolução da cultura (música e cinema) através do crioulo. Quanto à metodologia da pesquisa, optamos por uma abordagem descritiva, a fim de retratar o tema proposto, com o intuito de descrever e demonstrar as peculiaridades do povo guineense e do português falado no país. O procedimento técnico escolhido é a pesquisa bibliográfica, com base em matérias coletadas que se debruçam sobre o assunto. O presente capítulo está divido em quatro subcapítulos, que procurará abordar essas questões levantadas acima.

\section{A língua oficial da Guiné-Bissau}

Segundo a definição da Martins (2014, p.14), "língua oficial é a língua [...] de um país, estado ou território usada nas diversas atividades oficiais: legislativas, executivas e judiciais". No entanto, a Constituição Nacional guineense não deixa isso claro, como em outros países lusófonos, em que a questão da língua portuguesa como língua oficial é bem explícita - casos da Constituição de Angola, Cabo-Verde e Moçambique. Na Constituição da Guiné-Bissau (1996, p. 6), no seu artigo $17^{\circ}$, ponto 1 , há a seguinte referência: "É imperativo fundamental do Estado criar e promover as condições favoráveis à preservação da identidade 
cultural, como suporte da consciência e dignidade nacional e fator estimulante do desenvolvimento harmonioso da sociedade". Como visto, em nenhum momento, é mencionado que a língua oficial do país é o português, e ainda reforça-se, nesse mesmo artigo, que: "O Estado preserva e defende o património cultural do povo, cuja valorização deve servir o progresso e a salvaguarda da dignidade humana" (Guiné-Bissau, 1996, p. 6). No entanto, apesar disso, considera-se a língua portuguesa como sendo a oficial do país.

De acordo com a definição de Martins e com o artigo da Constituição acima citados, podemos afirmar que a língua portuguesa não se enquadra como oficial do país em função de dois pontos que, para muitos, são os requisitos mais importantes a que uma língua oficial de qualquer país deve atender, a fim de ter as bases propícias para se apresentar em todo o território nacional: 1) a língua dita "oficial" na Guiné Bissau não domina os trabalhos tanto no poder legislativo quanto no judiciário, pois pouco se discute as suas matérias em português. Ainda mais, os debates na Assembleia Nacional Popular, e os julgamentos nos tribunais da capital e, muito menos, no interior do país não são realizados em português; 2) Igualmente, é possível constatar que o povo não usa o português no seu dia a dia.

A língua considerada oficial (o português), portanto, praticamente não configura como a língua de comunicação entre os guineenses. Inclusive, na ecologia linguística do país, existe até uma língua étnica com maior número de falantes do que o português, como é o caso da língua fula, em quantidade absoluta de falantes. Segundo o INE (2009, p. 22), "Fulas correspondem à etnia com maior expressão no país (28,5\%)". E seguido de perto pela língua balanta com $22,5 \%{ }^{1}$. Por sua vez, observa-se que o português é falado por cerca de $27,1 \%$ da população (INE, 2009, p.36). Ainda assim, uma parte da população fala essa língua do colonizador de forma ocasional e profissional, só nos lugares onde a língua crioula por vezes é pouco usada, no caso das escolas e nas instituições do Estado e privadas. Importa enfatizar que, nesses lugares, há uma "disputa" enorme entre crioulo e português. Nesse sentido,

\footnotetext{
O português até hoje não é praticamente falado como língua vernácula na Guiné-Bissau. Ele só é adquirido como língua primeira, materna, por uma insignificante franja de filhos de guineenses que, tendo estudado em Portugal ou no Brasil, adotaram-no como língua de comunicação familiar, ou por filhos de casais mistos de guineenses com falantes de português de outras nacionalidades. É também o caso de filhos de portugueses residentes na Guiné-Bissau ou, então, de filhos de outros estrangeiros que por um motivo ou outro falem português em casa (Couto; Embaló, 2010, p. 47-48).
}

1. É importante ressaltar que esse é o número total das pessoas que pertencem a esses grupos étnicos, mas isso não significa que todos sabem falar a língua do grupo, a maioria sim, alguns até conseguem falar mais de que uma língua étnica. É possível deparar com esses casos nas famílias constituídas por etnias diferentes ou nas pessoas que cresceram num ambiente onde predomina uma determinada etnia e outros tipos de contatos. 
A maioria da população que fala o português está concentrada na cidade de Bissau, com isso, a língua portuguesa limitou-se praticamente à capital do país e a grandes centros urbanos do interior da Guiné-Bissau. Assim, grande parte da população de todo o território nacional não usa essa língua - fato que não acontece e continua longe de acontecer, por causa do espaço conquistado pelo crioulo e pelas línguas étnicas ao longo dos anos.

Segundo o relatório do Ministério de Educação de Portugal, publicado no Diário de Notícias (19/06/2017), "a percentagem de alunos que ficaram reprovados na $2^{\mathrm{a}}$ fase no português foi de $52 \%$ ". Isso mostra a complexidade da questão do ensino de língua portuguesa, pois mesmo os estudantes de outros países que têm o português como língua única, diferente dos estudantes da Guiné-Bissau, também têm dificuldades nessa disciplina. Essa situação pode ser justificada em função dos métodos que são usados no processo de ensino e aprendizagem nesses países - lembrando que a Guiné-Bissau herdou o sistema educacional colonial em que o português é ensinado só levando em conta a sua base gramatical. De acordo com mesmo relatório citado acima, "mais de metade dos alunos do 9.

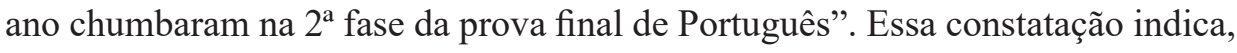
em parte, que a precariedade e os problemas na educação da Guiné-Bissau não se limitam exclusivamente à questão da língua portuguesa, ou o uso do crioulo e das outras línguas étnicas no cotidiano dos estudantes guineenses.

O fraco domínio do português na educação e na vida dos guineenses também se reflete no fraco desempenho dos alunos nas salas de aulas, causando enorme dificuldade na compreensão dos conteúdos escolares. Nesse sentido, esse fraco uso acaba deixando os guineenses mais tímidos e reservados ao se expressarem perante os outros e, por questões de segurança, às vezes optam por ficar calados ou recorrendo ao crioulo como recurso para expor os seus sentimentos. Devido a estes fatores, de não consolidação da língua portuguesa em todo o território nacional, as crianças sofrem com o ensino dessa língua, enfrentando muitas dificuldades na compreensão dos textos a serem estudados. Desta forma,

\footnotetext{
os alunos não percebem a língua portuguesa. Leem mas não compreendem o texto, alguns alunos não escrevem o português correto. Como é que um estudante que não escreve e nem fala correto à língua portuguesa pode compreender e interpretar um texto nesta língua? Às vezes compreendem melhor quando a explicação é na língua crioula, eu já tive essa experiência. Por vezes [...] é preciso desenhar bem as coisas para fazer alguns alunos compreender em língua portuguesa (Barreto, 2012, p. 26).
}

Como é sabido, o fraco uso de qualquer língua também contribui negativamente no desempenho da escrita. Por isso, é validada a importância do uso do português, não só nas escolas, nas instituições do Estado, assim como em todos os meios sociais. A partir dessa postura, o próprio povo passará a interessar-se 
mais pelo português, o que trará enormes vantagens para o progresso dos alunos nos seus estudos e aprendizagem, já que é o português a língua do ensino no país.

\section{Língua crioula (kriol/guineense)}

Segundo Embaló (2008, p. 102), "o kriol é um crioulo de base portuguesa, com uma gramática e léxico próprios". Ele é o principal meio de comunicação ente os guineenses, contando com cerca de 90,4\% de falantes (INE, 2009, p. 36), de diferentes classes e etnias. Ainda de acordo com Embaló, "o crioulo surgiu através do contato do português com as várias línguas africanas, facilitando a comunicação não só entre os europeus e os africanos, como também entre os próprios povos, dada a diversidade linguística da região, [...] entre o fim do século XVI e início do século XVII" (Embaló, 2008, p.124), e vem conquistando o seu espaço ao longo do tempo. Conforme Augel (2006, p. 69), "o crioulo teve a função social de língua veicular entre os falantes de origens as mais diversas, passando ao estatuto de idioma autônomo, tanto do ponto de vista gramatical quanto lexical. Hoje é considerada língua da unidade e da identidade nacionais".

Não obstante, apesar de seu franco uso, não existe ainda uma norma escrita, ou melhor, uma normatização ortográfica do crioulo, mas já existem alguns dicionários e livros escritos nessa língua por entidades particulares, nomeadamente as Igrejas Evangélicas e algumas ONGs. As Igrejas Evangélicas são as pioneiras na elaboração de dicionários do crioulo, como também na tradução desses para as línguas étnicas e de dublagem de filmes (filmes cristãos). Assim sendo, é necessário observar a complexidade plurilinguística do país, pois, embora o português seja a língua oficial da Guiné-Bissau e, consequentemente, a língua oficial do ensino, continua até aos dias de hoje como a segunda, ou até a terceira língua mais falada no país, dependendo do caso. Isto é, dependendo da constituição da família, a primeira língua pode ser o crioulo, depois a língua étnica a que a família pertence e, por último, o português. Essa ordem pode mudar substancialmente, principalmente no interior do país, onde, na maioria dos casos, a primeira língua é a do grupo étnico a que a família pertence seguida pelo crioulo como a segunda língua da família.

O português, na maioria das famílias no interior do país, é considerado como uma língua estranha; sequer é falado no seio dessas famílias, salvo pelas crianças que frequentam as escolas, mas mesmo neste caso, elas só falam o português em ambiente escolar, pois em casa falam o crioulo ou a línguas étnicas as quais pertencem. Assim sendo, apesar de a língua mais falada no país, no dia a dia da população, dos estudantes e os políticos, ser o crioulo, nas escolas se ensina em língua portuguesa - língua que não se consolidou socialmente no 
país. Ainda assim, o crioulo tem uma importância grande na vida cotidiana do povo, uma vez que congrega elementos fundamentais para a comunicação na Guiné-Bissau.

Diferente daquilo que acontece em vários países do continente africano, onde existem várias línguas étnicas, mas a língua do dia a dia é a do colonizador, na Guiné-Bissau a língua do dia a dia é a língua crioula. Ela serve como língua intermediária no cotidiano da população. Ainda sobre o crioulo, é preciso salientar que são pouquíssimos os países com essa caraterística, ou seja, o povo guineense possui uma língua que não é étnica, mas que é falada e compreendida por quase toda a população e, que não é também a língua do colonizador.

Haveria vantagens e desvantagens se o crioulo fosse à língua oficial da Guiné-Bissau ou a língua do ensino no país: as vantagens são inúmeras, começando pela facilidade na compreensão e na expressão, sendo a língua materna e de contato da maioria dos guineenses. Essa situação ajudaria também na compressão das outras línguas estrangeiras, incluindo o português, uma vez que deixa o indivíduo com mais facilidade tanto na fala quanto na escrita por ser a língua do seu domínio. No que toca às desvantagens do crioulo no seio dos guineenses, deve-se ao fato de não ser a língua de trabalho e de ensino no país, afetando muito aos guineenses em função de terem mais domínio de crioulo em relação ao português - lembrando que o crioulo não tem ainda uma escrita padronizada que poderia ajudar muito mais no progresso dos falantes. Essa realidade traz impactos negativos para o avanço da educação em geral e, particularmente, no processo de ensino e aprendizagem na Guiné-Bissau, não apenas na disciplina de língua portuguesa, mas também em outras, pois essa é a chave para a compreensão dos materiais curriculares.

\section{O processo linguístico-educativo na Guiné-Bissau}

A língua é um fator importantíssimo para qualquer que seja a comunidade e a cultura (civilização), pois é com ela que podemos estabelecer a comunicação e, consequentemente, o diálogo que faz criar o ambiente de inter-relações entre os indivíduos e da produção do conhecimento, sem o qual este processo ficaria comprimido. Por esses motivos, Freire (2011), acredita que a melhor forma de ensinar é por via da linguagem maternal, que é a língua que as pessoas têm mais probabilidade de dominar através do contato permanente. Não existe nada igual a aprender um conteúdo na língua que domina, haja vista que não só facilita a assimilação do conhecimento como também deixa os aprendentes mais animados, fato que traz, com certeza, grande produtividade e eficácia na hora de passar o que se aprende para outras pessoas (caso dos professores). 
Em muitas escolas na Guiné-Bissau, os alunos são obrigados a falar o português nos recintos escolares, mas, mesmo com essa determinação, eles falam crioulo entre si para a melhor comunicação. Nós vemos essa proibição como uma inversão de papel, ou seja, há casos em que o professor sente que o aluno entende o conteúdo, mas na hora de falar o pró́be de se comunicar em crioulo, ao ponto de esse aluno levar nota baixa só porque não consegue explanar em português. Por isso, os alunos se preocupam mais em decorar o dicionário e a gramática, em detrimento da prática discursiva, tudo por medo de errar. Pode-se ver, em vários casos, que o professor corrige o aluno o tempo todo e os colegas ficam zombando dele - comportamento que deixa o aluno com mais medo e vergonha de falar, para não levar a zoada dos colegas. Contudo, consideramos que

A questão da linguagem, no fundo, uma questão de classe, é igualmente outro ponto em que pode emperrar a prática pro $\neg$ gressista. Um educador progressista que não seja sensível à linguagem popular, que não busque intimidade com o uso de metáforas, das parábolas no meio popular não pode comunicar com os educandos, perde eficiência, é incompetente (Freire, 2001, apud Cortesão, 2011, p. 100).

Segundo Cá (2010), o Estado poderia verificar o quadro de dificuldades que o sistema educativo enfrenta de forma a amenizar os obstáculos do sistema com relação à questão da língua, pois, para ele, a linguagem não é usada apenas para veicular informação. Assim sendo, sua função referencial ou denotativa não é senão uma entre outras, em que se destaca a função de locutor e interlocutor. Portanto, devem ser tomadas as medidas cabíveis pelos órgãos oficiais, a fim de se atender pelo menos as exigências comunicativas básicas.

É imperioso reconhecer que esse problema não se limita apenas à formação dos professores, se dominam os conteúdos ou não e nem aos alunos, que na maioria dos casos são vítimas do próprio sistema. Não são esses dois agentes os responsáveis pelo fracasso da educação guineense, pelo contrário, trata-se dos verdadeiros prejudicados nesse sentido. Os alunos passam por essas situações devido ao fraco domínio em língua portuguesa, pois os primeiros contatos com a língua, na maioria dos casos, acontecem quando começam a frequentar as salas de aulas.

Esse contato, no entanto, não é suficiente para se familiarizarem com a língua, se levarmos em consideração o tempo em que eles ficam nas escolas, ou seja, o tempo da duração das aulas e, consequentemente, em contato com o português. Conforme demonstra o quadro 02 , eles falam a língua durante as aulas, em média as aulas duram 4 horas por dia, que são também 4 horas da prática com a língua portuguesa diariamente, o que totalizam 20 horas por semana, de segunda-feira à sexta-feira. O resto das horas é preenchido com a língua crioula e, em alguns lu- 
gares, pelas línguas étnicas a que pertencem o aluno, incluindo os fins de semana e nos dias feriados. Sabemos que só a língua não garante uma boa qualidade da educação, mas ela é um dos fatores importantes para atingir esse objetivo.

Quadro 2: Contato com o português e com o crioulo

\begin{tabular}{|c|c|c|}
\hline \multicolumn{3}{|c|}{ Contato dos alunos com a língua } \\
\hline & Portuguesa & Língua crioula/étnica \\
\hline Por dia & 4 horas & 20 \\
\hline Por semana & 20 horas & 140 \\
\hline
\end{tabular}

Fonte: Sampa (2016, p.38).

Essas horas correspondem aos momentos exatos em que os alunos ficam em contato direto com a língua portuguesa, que é a língua do ensino no país. Esse tempo, na nossa avaliação, é muito pequeno, ao se tratar duma língua do ensino e oficial. A questão da língua é muito fundamental na educação, pois a comunicação é o principal motor nesse processo (ensino). A sociedade guineense está fortemente dominada pela língua crioula, por isso deve merecer muita atenção. Na verdade, "não é a educação que forma a sociedade de certa maneira, mas a sociedade que, formando-se de certa maneira, constitui a educação de acordo com os valores que a norteiam." (Freire, 2011, p. 146). Dessa forma, podemos admitir que aquilo que acontece na Guiné-Bissau é totalmente diferente, pois a educação implementada pelo Estado guineense, até certo ponto, não condiz com a realidade da sociedade, uma vez que os materiais escolares são produzidos em Portugal, sem a mínima preocupação com a realidade linguística dos alunos.

\section{Particularidades da língua portuguesa na Guiné-Bissau}

A força da língua crioula na Guiné-Bissau tem também um impacto muito grande no jeito de falar o português. Por esse e por outros motivos, facilmente um lusófono reconhece o português de um guineense, como também o português de um angolano ou de um moçambicano etc., em função das influências das línguas étnicas existentes nesses países africanos. Esses fatos são naturais e acontecem em qualquer língua, pois a língua se move de acordo com a comunidade linguística em que é praticada. Por exemplo, nos casos em que uma pessoa adquire a segunda língua, os traços da primeira sempre influenciam na segunda, pelo menos na fala, porque a nossa mente já tem armazenado outros códigos linguísticos que acontecem de uma forma natural em todos os seres humanos, desde os primeiros contatos com essa língua, nesse caso o nosso cérebro acaba cedendo às regras da sociedade a nível linguístico: 
Inicialmente, o aprendiz geralmente busca aprender uma L2 depois de uma certa idade, o que gera uma implicação psicolingüística de que quem aprende uma L2 traz consigo um outro sistema lingüístico, que é o da L1. Por esse fato, o aprendiz que já possui um sistema de hábitos musculares e neuromusculares, terá que substituir esse sistema gradativamente pelo da L2 (Sapucaia, 2014, p. 6).

A Guiné-Bissau tem as suas próprias características típicas no modo como falamos a língua portuguesa. Ou seja, o português é fortemente influenciado pelas características do crioulo. No crioulo, por exemplo, não se verifica a concordância em número e em pessoa como acontece no português padrão:

Exemplo 1: crianças sta animado (as crianças estão animadas); criança sta animado (a criança está animada).

Exemplo 2: cada quem com seu par (uma das variedades da Guiné-Bissau); cada um com seu par (português padrão).

Exemplo 3: o número mais grande (uma das variedades da Guiné-Bissau); o número maior (português padrão).

Como se pode observar, no exemplo 1, o verbo "estar" em português se encontra na terceira pessoa do plural, por isso concorda com o sujeito, diferente do crioulo em que não ocorre a concordância com o sujeito. Em seguida, temos o exemplo do adjetivo animadas (em português) que está concordando em gênero (feminino) e número (plural) como o substantivo a que se refere: crianças.

Tanto no exemplo 2 quanto no 3, há destaque para os termos (cada quem e mais grande), que são transportados do crioulo para o português, por portarem a mesma carga semântica do português. Por isso, alguns falantes recorrem a eles ao falarem o português, partindo dos seus significados no crioulo, sem se levar em consideração os contextos em que vão sendo empregados no português.

Ainda, casos como esses levam alguns falantes a confundirem esses fenômenos com os do português padrão, fato que ocorre até com algumas pessoas com nível mais avançado na língua portuguesa. É importa enfatizar que, mesmo com essas particularidades, alguns falantes ainda não se orgulham da variedade típica do português da Guiné-Bissau, pelo contrário, se esforçam muito em falar do mesmo jeito que os falantes de Portugal, coisa praticamente impossível, já que não pertecem a mesma comunidade linguística dos portugueses. Às vezes, isso acaba induzindo a pessoa a erro, pois os próprios portugueses têm suas próprias variedades diferentes.

Essa tentativa de imitar o sotaque de Portugal deve-se ao prestígio social e a pouca valorização da variedade do português guineense. Esse fraco uso do português leva os guineenses a não se identificarem com a sua variedade própria, passando a ver o português como a língua que não lhe pertence (exportando as outras variedades linguísticas). Entretanto, não há ou pouco se sabe sobre a 
política linguística da Guiné-Bissau, muito menos sobre a preocupação do Estado e dos linguistas em estimular as pessoas a falarem a língua portuguesa de acordo com a realidade linguística do país.

$\mathrm{Na}$ sociedade guineense, a pessoa pode ser "inteligente", com amplo conhecimento, reconhecido a nível internacional, mas basta não ter domínio em português isso já é suficiente para não ser visto como tal. Dessa forma, o português de Portugal é sinônimo de "inteligência". Quanto mais a pessoa imitar o sotaque de Portugal, mais admiração receberá da sociedade. Por isso, quem não possui um forte domínio, principalmente daquela variedade que se aproxima de Portugal, prefere falar outra língua que não seja o português para não receber zoadas, pois os guineenses até hoje veem o português de Portugal como o mais certo e adequado, fato esse motivado por falta de conhecimento sobre as outras variedades como as de Madeira e Açores, que são diferentes da variedade considerada padrão e que é falada em Lisboa e Coimbra. Se em Portugal existem variedades linguísticas diferentes, imagina na Guiné-Bissau que possui inúmeros fatores linguísticos, sociais e culturais que influenciam fortemente na fala do guineense.

Daí a importância de um trabalho de base e de conscientização de toda a população sobre a língua portuguesa, a fim de mostrar que o português na Guiné-Bissau só conseguirá afirmar-se quando as pessoas o praticam levando em conta a realidade guineense, através de sua variedade própria, já que na Guiné-Bissau existem várias línguas à volta do português e que algumas delas são mais faladas que o próprio português. Atualmente, inclusive, nota-se uma forte presença do francês em detrimento do português, em que se vê mais interesse da população em aprender e falar o francês do que o português.

Esse trabalho tem que ser feito por linguistas, com o intuito de evidenciar que a variedade linguística não tem que ser importada, mas sim produzida e praticada com orgulho, independentemente da comunidade em que a língua vai ser usada, porque cada comunidade tem a sua particularidade devido às suas próprias línguas étnicas. Um dos fatores dessa pouca presença do português, entre outros, deve-se ao fato da rejeição por parte do guineense ao processo da colonização, dando mais valor ao que é dele em forma de resistência ao domínio colonial.

De acordo com Fafina (2011), não há como separar a língua da cultura, já que em qualquer país elas andam juntas. Por esse motivo, é difícil desassociar as duas. A sociedade guineense apresenta fortemente os traços da língua crioula e das línguas étnicas, fatores que refletem diretamente no jeito de falar o português por parte dos guineenses.

Ao contrário dos outros países, na Guiné-Bissau, as línguas étnicas, raras vezes, influenciam diretamente o português. Às vezes, acontece só no sotaque de 
alguns falantes, levando em consideração que esse falante já tinha aprendido outra língua antes do crioulo e posteriormente o português, por essas razões o sotaque desse indivíduo carrega certos laços dessa primeira língua (língua materna). Além disso, as línguas étnicas da Guiné-Bissau não interferem de forma visível no português, como, por exemplo, as gírias e a introdução direta das palavras, fato que acontece noutros países. No caso específico da Guiné-Bissau, a cultura, principalmente a língua crioula, é que está impactando muito o português falado hoje no país:

Por isso o português falado em Guiné-Bissau apresenta suas peculiaridades e se distância das variedades faladas em outros países de língua portuguesa, tendo em vista que a formação social e cultural dos países lusófonos é diferente (Fafina, 2011, p.8).

Para tanto, se levarmos em consideração o que citamos acima, principalmente na questão do mosaico cultural que existe na Guiné-Bissau, composto por várias línguas e culturas diferentes uma da outra, essas particularidades devem ser apuradas e reconhecidas, como uma riqueza cultural fruto de uma sociedade com as caraterísticas pluriculturais.

\section{Poder da língua crioula na cultura e na identidade guineense}

Conforme Burke, a cultura é "um padrão, historicamente transmitido de significados incorporados em símbolos, um sistema de concepções herdadas, expressões em formas simbólicas, por meio das quais os homens se comunicam, perpetuam e desenvolvem seus conhecimentos [...]" (Burke, 2004, p.16). Portanto, a partir dessa definição, a língua crioula pode ser enquadrada como uma forma de expressão cultural da Guiné-Bissau.

O poder do crioulo na cultura guineense em todos os âmbitos é de extrema importância, pois leva a cultura guineense pelo mundo. Através dele, a cultura do país é conhecida, principalmente a música, o teatro, a literatura e o cinema. Segundo Embaló (2008), o crioulo foi o impulsionador da música popular, pois as canções das mandjuandades e gumbé são quase todas interpretadas em crioulo (algumas nas línguas étnicas), também os cânticos à guerrilha que aconteceram na Luta Armada de Libertação Nacional da Guiné-Bissau, o que deu mais força e coragem para os combatentes durante os processos de luta.

Mandjuandades são agrupamentos de indivíduos de ambos os sexos, da mesma faixa etária, com uma estrutura social específica e hierarquizada, que se confraternizam em festas e encontros sociais. Gumbé é um gênero musical que surgiu da junção de alguns ritmos de diferentes grupos étnicos da Guiné-Bissau, (como tina, kussundé, djambadom, kunderé, etc.) Tem como os 
principais instrumentos a calabaça (kabaz) e sikó, este último, é também um estilo musical na Guiné-Bissau.

Em quase tudo que se faz na Guiné-Bissau, principalmente na área da cultura, a língua crioula está presente. Mesmo não sendo a língua oficial do país, o crioulo não deixa de ser o fator de grande relevância para a elevação das diferentes áreas da cultura, pois é com ele que o guineense consegue se expressar, aliás, o guineense, mesmo falando bem o português, sente-se mais à vontade ao falar em crioulo. Em todo esse processo da afirmação da cultura nacional, o crioulo foi sempre peça chave, até chegar à música moderna guineense, com o falecido José Carlos Schwarz, conhecido por muitos como Zé Carlos, o pioneiro da música moderna do país. Além disso, a banda desenhada (no Brasil, conhecida como histórias em quadrinhos) teve o seu início também com o crioulo, ou seja, as primeiras edições foram apresentadas na língua do povo guineense. Conforme Embaló, (2008, p.104) "a banda desenhada foi inaugurada em língua crioula na década de oitenta do século passado". Por tudo isso, afirma-se que o crioulo consegue transmitir uma identidade cultural muito forte entre os falantes, por isso que até os artistas, autores e pessoas ligadas à área da cultura preferem fazer os seus trabalhos em língua crioula de forma a atingir mais o povo guineense em relação à língua portuguesa.

Quase todos os escritores guineenses escreveram e escrevem, até hoje, em crioulo. Contudo, a maioria das obras é escrita em português, isso devido a diferentes fatores, como a questão da "internacionalização" dos seus trabalhos, mesmo assim muitos deles continuam a escrever no crioulo. Conforme Augel (2007, p. 171), "é possível constatar, em quase todos os autores guineenses contemporâneos, a desenvoltura com que escrevem em crioulo e como essa língua é parte integrante do seu universo". Existem várias obras escritas em português, mas com a introdução de algumas palavras da língua crioula.

A língua guineense é também onipresente na poesia em português de Felix Sigá (1996). [...] O poeta não só introduz na enunciação em português muitos termos e expressões em crioulo, dando o tom de oralidade à fala das personagens, como emprega construções daquele idioma nos enunciados em português (Augel, 2007, p. 171).

Em todas as etnias, os rituais de iniciação são uma fase importante para a comunidade em geral e para as pessoas que vão passar de uma fase para outra. Dependendo das etnias e famílias, essa é uma das fases mais importantes e perigosas para o indivíduo, pois ali o iniciante já está preparado para assumir outra postura perante a comunidade e as pessoas esperam isso dele. É perigoso porque, em caso de descumprimento das normas do grupo durante esse processo, pode 
até levar à morte do iniciante. Em todo esse processo, é comum falar a língua do grupo étnico a que a pessoa pertence, ou seja, é muito raro nessas cerimônias se falar outras línguas - menos nos rituais que acontecem na capital Bissau, onde, às vezes o crioulo entra, mas isso não acontece em todas as etnias.

Nos meios de comunicação, a disputa do crioulo com o português é muito grande, pois em cada um há o predomínio de uma língua. Nas mais de dez grandes emissoras de rádios da capital Bissau, o crioulo predomina em grande parte das grelhas de programação, salvo em alguns noticiários e programas que são emitidos em português. Em mais de duas dezenas de rádios espalhadas no interior do país, o crioulo fala mais alto, dando também ênfase à língua da etnia que predomina em cada cidade. $\mathrm{O}$ crioulo tem uma grande vantagem nesse meio de comunicação, pois consegue atingir quase todos os grupos étnicos. Por esse, e por outros motivos, a língua crioula vem ganhando mais espaço na Guiné-Bissau. Se nas rádios o crioulo predomina, nos jornais impressos e televisão (TGB), o português reina quase que em absoluto. Pouquíssimos programas passam em crioulo na televisão, muito menos nos jornais impressos, em que o crioulo não é usado para escrever as notícias - às vezes é usado apenas para contar uma história no final do jornal impresso ou para destacar um acontecimento em banda desenhada (histórias em quadrinhos).

Ainda está na nossa memória o filme "Mortu Nega" (em português, "A Morte Rejeita"), de um cineasta guineense Florentino Gomes, conhecido por Flora Gomes, que foi produzido em crioulo. Trata-se do primeiro filme da Guiné-Bissau e que teve a sua estreia mundial no festival de Veneza (Itália), em agosto de 1988. Assim sendo, observa-se que a cultura do país é construída de diferentes formas, mas sempre com o crioulo como instrumento de trabalho, e sempre representando a identidade nacional, deixando as marcas fortíssimas em todas as áreas ligadas à cultura. Portanto, o crioulo afirmou-se como fator principal da elevação da cultura guineense ao mais alto nível e é reconhecido mundialmente como a língua de unidade nacional da Guiné Bissau.

\section{Considerações finais}

O poder que a língua crioula tem na Guiné-Bissau é tão grande que, ao tentar descrevê-lo aqui, não será possível esgotá-lo, pois ela conseguiu penetrar e até influenciar no imaginário da população guineense, porque não tem forma melhor de sonhar, planejar e projetar que na sua própria língua materna. No contexto da Guiné-Bissau, o crioulo dá um suporte comunicativo imprescindível, não só para a população se expressar melhor e à vontade, como também para excluir o receio de errar no espaço público, como acontece com grande parte dos guineen- 
ses quando fala o português. O crioulo consegue dar aos guineenses esses dois suportes (racional e expressivo), que são fundamentais para o desenvolvimento intelectual de qualquer indivíduo. Posto isto, o crioulo deveria ser a língua oficial da Guiné-Bissau a par do português, até porque é a língua com que o guineense se identifica mais.

No que concerne à sua contribuição na cultura guineense, podemos afirmar que o crioulo é o fator principal da evolução dessa área, pois é impensável falar da cultura guineense em qualquer aspecto sem levar em conta a língua crioula. Ela tem contribuído muito para a ascensão da cultura nacional, reconhecida e admirada por muitos em todos os setores que a cultura engloba, desde literatura, através de muitas obras publicadas dentro e fora do país, incluindo o teatro, em que a cultura guineense está também a trilhar os seus caminhos de forma brilhante. Sem esquecer-se da música crioula que toca em todos os cantos, com os seus artistas conhecidos e reconhecidos em outros países e continentes. Fatos que se verificam também nas outras línguas étnicas para elevação da cultura guineense.

Vemos, portanto, um povo com uma grande diversidade linguística, dominada pela linguagem falada, com mais de 20 línguas étnicas, em paralelo com o crioulo, mesmo que marcado pelos dialetos e sotaques próprios de cada etnia, com um discurso característico e um modo dinâmico de utilizá-lo que identificam e caracterizam o povo guineense. Essa realidade não é imposta, mas sim natural. Daí a importância de que os órgãos oficiais passem a considerar o crioulo como língua oficial. Além disso, é também fundamental que se leve em conta os aspectos que condicionam as variedades do português guineense, pois a língua se move de acordo com as diversidades culturais de cada comunidade linguística. Neste caso, nós vemos o crioulo como forte candidato para ser a língua de ensino na Guiné-Bissau, por ser a língua que congrega todas as outras línguas e que é falada por todas as pessoas que frequentam as escolas, sem deixar de lado o português que já tem raízes firmes em termos de estrutura e de contato com o mundo no que se concerne à cooperação com outros países e para pesquisas. $\mathrm{O}$ crioulo não só carrega o aspecto cultural e identitário guineense, como também facilita ao aluno a assimilação dos conteúdos a serem estudados e, neste caso, o português seria a ponte para esse aprendizado, andando sempre junto com o crioulo.

De modo geral, tanto as hipóteses como os objetivos propostos para este capítulo se confirmaram, uma vez que o português falado no país realmente tem uma variação e o crioulo contribuiu muito para que esse fato ocorra como também do seu impacto no cotidiano dos guineenses e na cultura nacional. Ele quebra todas as barreiras existentes no tocante às múltiplas línguas que se cruzam na Guiné-Bissau. É importante destacar que o português e o crioulo são duas línguas, mas 
nenhuma tem o seu espaço próprio, em todos os lugares é possível ver essa disputa, cada uma tentando conquistar um lugar.

\section{Referências}

Augel, Johannes. O crioulo da Guiné-Bissau. Afro-Asia, v.19, n²0, p.251-254, 1997. Disponível em: <https://portalseer.ufba.br/index.php/afroasia/article/viewFile/20957/13560>. Acesso: 22 fev. 2017.

Augel, Moema Parente. O desafio do escombro: nação, identidade e pós-colonialismo na literatura da Guiné-Bissau. Rio de Janeiro: Garamond, 2007.

Augel, Moema Parente. O crioulo guineense e a oratura. Scripta, Belo Horizonte, v.10, n.19, p.69-91, $2^{\circ}$ sem., 2006. Disponível em: <http://portal.pucminas.br/imagedb/documento/DOC_ DSC_NOME_ARQUI20070621145422.pdf>. Acesso: 12 abr. 2017.

Barreto, Maria Antónia. Reformas recentes no sistema educativo da Guiné-Bissau: compromisso entre a identidade e a dependência. IICT - Instituto de Investigação Científica Tropical e ISCSP. Instituto Superior de Ciências Sociais e Políticas da Universidade Técnica de Lisboa UTL. Lisboa: 2012.

Burke, Peter. O que é história cultural? Rio de Janeiro: Jorge Zahar Editor, 2004.

Cá, Lourenço Ocuni. Políticas públicas e gestão educacional. Cuiabá: EdUFMT, 2010.

Cortesão, Luiza. Porquê Paulo Freire e Amílcar Cabral? ECCOS: Revista Científica. São Paulo, n. 25, p.95-108, jan./jun. 2011. Disponível em: <https://sigarra.up.pt/fpceup/pt/pub_geral.show_ file?pi_gdoc_id=566282>.Acesso: 19 jun. 2016.

Couto, Hildo H. do; Embaló, Filomena. Literatura, língua e cultura na Guiné-Bissau: um país da CPLP. Revista Brasileira de Estudos Crioulos e Similares. Brasília: Thesaurus editora, n. 20, 2010.

Diário De Noticias. 2. ${ }^{a}$ fase: maioria dos alunos do $9 .^{\circ}$ ano chumba a português e matemática. Disponível em: < http://www.dn.pt/sociedade/interior/2a-fase-maioria-dos-alunos-do-9o-ano-chumba-a-portugues-e-matematica-5323386.html>. Acesso: 19 jun. 2017.

Embaló, Filomena. O crioulo da Guiné-Bissau: língua nacional e factor de identidade nacional. PAPIA, nº18, p.101-107, 2008. Disponível em: <http://revistas.fflch.usp.br/papia/article/viewFile/2027/1848>. Acesso: 19 jun. 2016.

Fafina, Danildo Mussa. Língua portuguesa: Guiné-Bissau e Brasil um caso de variação linguística. p. 1-13, 2011. Disponível em: < http://www.didinho.org/Arquivo/ARTIGO\%20DE\%20 DANILDO\%20II\%20CIDS.pdf>. Acesso: 25 fev.2017.

Freire, Paulo. Educação como prática da liberdade. 14ed., Rio de Janeiro: Paz e Terra, 2011.

Guiné-Bissau. Instituto Nacional de Estatística e Censo. $3^{\circ}$ Recenseamento geral da população e habitação. Bissau: INEC, 2009.

Guiné-Bissau. Constituição da República da Guiné-Bissau. Bissau: Assembleia Nacional Popular, 1996. 
Martins, Maria Filomena Bernardo. O ensino não formal na aprendizagem de português língua estrangeira em contexto de acolhimento: um estudo de caso. 2014, 163f. Dissertação de Mestrado. Faculdade de Letras, Universidade de Lisboa. Lisboa: UL, 2014.

Sampa, Pascoal Jorge. O que dizem as pesquisas sobre o contexto educacional na África lusófona: um mapeamento da produção técnico-científico sobre educação na Guiné-Bissau. 2016. 64f. Instituto de Humanidades e Letras, Universidade da Integração Internacional da Lusofonia Afro-Brasileira, Redenção: 2016.

Sapucaia, Michele Kovacs de Lima. Aquisição e Aprendizado: dois processos no Ensino de uma Segunda Língua. Centro de Comunicação e Letras, Universidade Presbiteriana Mackenzie. São Paulo-SP, s.p. 2014. Disponível em: <http://www.mackenzie.com.br/fileadmin/Graduacao/ CCL/projeto_todasasletras/inicie/MicheleSapucaia.pdf>. Acesso: 24 mai. 2017. 